\title{
PEREMPUAN DAN PEMBERDAYAAN EKONOMI KELUARGA MELALUI PEMBUATAN PONGASI DI DESA WENGGUDUKU KABUPATEN KONAWE
}

\author{
Syamsumarlin \\ Jurusan Antropologi Fisip Uninversitas Haluoleo Sulawesi Tenggara \\ Email:faqil_ancu03@yahoo.com \\ Telepon: 081342710206
}

Abstract

As it has been known, traditional alcoholic drink namely pongasi are made by Wengguduku peoplein Konawe district. Pongasi production has been a tradition of the people of that village as well as to earn money which is difficult to leave particularly by housewives of the village because this sort of drink is delivered in ceremonies among the societies. Besides, the production support their economic condition financially. Although the state forbids the production of pongasi, the housewives in the village still produce the drink due to tradition consideration. Based on that reality,social impact which is caused by pongasi distribution will be observed by etnoghraphy method by collecting data by collecting data, observation and interview towards research object based on field data. The result of this research will be considered as reference for antropologhy of law for the society.

Seperti diketahui, minuman keras tradisional yang disebut pongasi banyak dibuat oleh warga desa Wengguduku Kabupaten Konawe. Pembuatan pongasi sudah menjadi budaya dan mata pencarian yang sulit ditinggalkan oleh ibu-ibu rumah tangga di desa tersebut, karena minuman tersebut selalu disuguhkan pada saat ada hajatan warga. Selain itu pembuatan minuman pongasi ini juga dapat digunakan untuk membantu mencukupi dan menopang ekonomi keluarga. Walaupun pongasi merupakan minuman yang dilarang oleh negara, namun para ibu rumah tangga ini tetap memproduksi dengan alasan budaya masyarakat selama ini. Berdasarkan realita tersebut, dalam penelitian ini akan diamati dampak sosial yang 
ditimbulkan dariperedaran pongasimenggunakan metode etnografimelalui pengumpulan data, pengamatan dan wawancara mendalam terhadap obyek penelitian berdasarkan realita di lapangan. Hasil penelitian tersebut kemudian dijadikan bahan kajian hukum antropologi bagi masyarakat.

Keywords: hukum, budaya, pongasi dan ekonomi keluarga.

\section{Pendahuluan}

Kata perempuan, berarti menunjuk kepada salah satu jenis kelamin. Hal ini dapat dilihat dalam kehidupan sosial perempuan selalu dinilai sebagai mahluk yang lemah dibanding laki-laki. Gejala seperti ini menentukan mode representasi sosial tentang status dan peran perempuan. Keadaan tersebut menempatkan kaum perempuan sebagai mahkluk yang lemah yang eksistensinya tidak begitu diperhitungkan. Namun perkembangan terbaru sebagian kelompok masyarakat menempatkan perempuan makin mandiri kalau sebelumnya dalam kehidupan simbiotik, tetapi sekarang menjurus pada kebebasan sebagaimana yang harus dimiliki oleh semua umat manusia.

Peran publik perempuan menjadi salah satu sumber daya manusia dalam pembangunan ekonomi. Hal ini disebabkan adanya kemampuan mengambil bagian, atau peran serta memberikan nilai tambah bagi kemajuan pembangunan. Oleh karena itu, peran perempuan sebagai penggerak penbangunan tidak dapat diabaikan. Keterlibatan perempuan dalam proses pembangunan dewasa ini sangat dibutuhkan terutama dalam era globalisasi seperti sekarang. Pekerjaan domestik perempuan sebagai ibu rumah tangga akan menciptakan pembinaan keluarga yang dinamis, harmonis, damai dan sejahtera. Pada setiap kebudayaan, perempuan dan laki-laki memiliki peran dan pola tingkah laku yang berbeda untuk saling melengkapi perbedaan kodrati dari kedua mahluk ini. Pembagian kerja secara seksual dengan begitu bersifat fungsional artinya berguna bagi masyarakat secara keseluruhan.

Fenomena pemberdayaan perempuan ternyata berperan penting terhadap kelangsungan hidup keluarga, baik berkenaan dengan pembinaan moral anak, maupun pemenuhan kebutuhan ekonomi keluarga sebagai salah satu pilar utama berlangsungnya kehidupan keluarga. Berkaitan dengan hal tersebut, menunjukan bahwa kaum perempuan sudah banyak terlibat 
secara aktif dalam membantu pemenuhan ekonomi keluarga. Salah satunya adalah fenomena munculnya buruh pabrik yang digeluti kaum perempuan di perkotaan maupun di daerah pedesaan. Hasil penelitian Warto dalam Abdullah (1997:157) di Desa Margomulya menunjukan bahwa setiap tahun jumlah penduduk yang bekerja di sektor non-pertanian dalam hal ini buruh pabrik bertambah sekitar $14 \%$, hasil penelitian ini karena jumlah buruh laki- laki dan perempuan tidak jauh berbeda, meskipun jumlah buruh laki-laki lebih banyak ( 74,67 \%) dari pada perempuan (46,43 \%). Dilihat dari perspektif gender jumlah itu mengisyaratkan adanya kedudukan dan kesempatan yang sama antara pria dan perempuan dalam mengakses pekerjaan di luar desa. Hal tersebut tentu saja tidak terlepas dari upaya kaum perempuan untuk membantu pemenuhan ekonomi keluarga.

Hal yang sama juga ditemukan pada kaum perempuan di daerah pedesaan Jawa Tengah. Hasil penelitian Kutanegara dalam Abdullah (1997:197) menunjukan bahwa kaum perempuan di daerah ini sebagian besar berprofesi sebagai perempuan bakul, yakni kaum perempuan yang umumnya telah berkeluarga telah melakukan aktifitas berdagang di pasar sebagai upaya untuk mencukupi kebutuhan keluarga, disamping usaha yang dilakukan kaum pria (suami). Fakta-fakta tersebut di atas membuka mata kita bahwa demikian besar peran kaum perempuan baik dalam aktivitas domestik maupun aktivitas politik.

Menyadari akan pentingnya potensi perempuan di Indonesia, pemerintah secara terarah telah memacu keikutsertaan kaum perempuan dalam angkatan kerja. Peningkatan perempuan pekerja oleh berbagai sebab dan dorongan, selain merupakan bukti kemampuan, juga umumnya karena kebutuhan sehari-hari sebagai motivasi dasar untuk bekerja. Sekalipun keinginan semula yang mendorong perempuan bekerja adalah positif, namun tidak lepas dari masalah-masalah yang timbul sebagai akibat perempuan bekerja, lebih-lebih bagi mereka yang telah berkeluarga. Sejumlah pakar psikologi memberikan gambaran pengaruh perempuan berkeluarga yang bekerja, baik terhadap keluarga, masyarakat maupun dirinya sendiri. Terdapat segi-segi yang menguntungkan, sekalipun umumnya mengandung beban yang berat bagi dirinya sendiri, terutama bila kurang mendapat pengertian dari suami dan anggota-anggota keluarga yang lain. Berbagai penelitian tentang perempuan yang berkeluarga dan bekerja, 
mengungkapkan pengaruh terhadap perubahan-perubahan yang terjadi misalnya dalam pola penggunaan waktu sehari-hari, sumbangan ekonomi terhadap keluarga, dan pandangan masyarakat terhadap perempuan yang bekerja di luar rumah.

Dalam setiap kebudayaan, perempuan dan laki-laki memiliki peran dan tingkah laku yang berbeda, namun saling melengkapi. Peran tersebut menyangkut hak dan kewajiban tertentu. Peran berhubungan dengan tindakan menurut status pada kelompok tertentu dan dengan situasi sosial. Peran bisa berubah dari waktu-kewaktu, sesuai dengan perbedaan sosial ekonomi dan masyarakat. Demikian pula dengan gender. Di mana peran perempuan dan laki-laki disesuaikan dengam status lingkungan dan budaya (Laksono, 2000: 10).

Berkaitan dengan upaya mengkaji konstribusi atau peran perempuan, maka dapat dilihat tiga peran kaum perempuan, sebagaimana di kemukakan oleh lhromi dalam Laksono (2000: 10) yakni : (1) peran produktif menyangkut kegiatan yang langsung menyumbang pendapat keluarga. Tanpa melihat apakah kegiatan tersebut dibayar atau tidak dibayar, misalnya petani dan petemak ; (2) peran produktif menyangkut kelangsungan hidup manusia dan keluarga, misalnya melahirkan, menyusui, memelihara dan mengasuh anak, mengambil air, memasak, membersihkan rumah, dan menjahit; (3) peran sosial, mencakup kegiatan yang tidak terbatas pads pengaturan keluarga tetapi jugs pads komunitasnya, misalnya peran dalam koperasi, kelompok tarsi dan sebagainya.

Studi empiris berkaitan dengan peran gender telah banyak dilakukan. Mosse (2003:5) mengungkapkan bahwa semua masyarakat memiliki pembagian kerja bedasarkan gender (gender division of labor) terdapat keberagaman kerja yang dilakukan laki-laki dan perempuan. Beberapa masyarakat seperti masyarakat Bali, masyarakat Mbuti di Afrika memiliki peran gender yang benar-benar tumpang tindih. Di kalangan orang kerdil dalam masyarakat Mbuti, Bwerburu bisa melibatkan lakilaki dan perempuan, laki-laki menangkap udang dan mencari kacang bila mereka menemukannya, laki-laki dan perempuan terlibat aktif dalam mengasuh anak. Sebaliknya dikalangan orang Amraha, normanya adalah ayah jarang menyentuh anak-anaknya selama dua tahun pertama kelahiran anak. Namun setelah usia anak dua tahun berturut-turut, ia mengharapkan kepatuhan sepenuhnya dan anak tersebut. 
Berdasarkan survey awal yang dilakukan peneliti, bahwa faktafakta seperti dinyatakan di atas juga terdapat juga di Desa Wonggeduku Kabupaten Konawe. 45\% aktifitas kaum perempuan di daerah ini yang umumnya telah berumah tangga berprofesi sebagai pembuat minuman pongasi dan sekaligus sebagai penjual. Profesi tersebut telah lama mereka lakukan sebagai penunjang atau menambahkan pendapatan suami. Karena melalui aktifitas menjual pongasi tersebutlah mereka akan memperoleh sejumlah uang yang berguna untuk memenuhi berbagai bentuk keperluan keluarga mereka. Selain itu membuat dan menjual pongasi sudah menjadi pencaharian, sebagian ibu-ibu di Kelurahan Wonggeduku. Hal ini di sebabkan karena permintaan terhadap jenis minuman ini masih tinggi dikalangan masyarakat yang ada di wilayah Kecamatan Wonggeduku. Namun pekerjaan membuat pongasi mengalami masalah karena adanya usaha pihak polisi untuk melarang masyarakat untuk mengkonsumsi minuman beralkohol termasuk pongasi. Kenyataan tersebut semakin meresahkan apabila muncul masalah sosial seperti perkelahian, kekerasan dalam rumah tangga, pencurian dan masalah sosial lainnya yang diakibatan karena pengaruh mengkonsumsi pongasi.

\section{Metode Penelitian}

Penelitian ini dilaksanakan di Kelurahan Wenggeduku Kabupaten Konawe. dengan pertimbangan bahwa di Kelurahan Wenggeduku terdapat perempuan pembuat pongasi jumlah cukup banyak. Mereka membuat dan kemudian menjualnya dengan berbagai strategi, karena minuman ini mengandung alkohol dan bisa memabukkan orang yang menkonsumsinya. Untuk memperoleh data atau informasi sehubungan dengan penelitan ini, maka peneliti memfokuskan proses wawancara dan pengamatan pada 5 (lima) orang Ibu rumah tangga dan keluarganya yang berprofesi sebagai pembuat pongasi sekaligus bertindak menjual minuman tersebut ke pasar. Nama yang dicantumkan dalam hasil penelitian ini merupakan nama samaran. Untuk menjaga privasi mereka yang sejak awal penelitian tidak ingin dituliskan dalam hasil penelitian ini. Kelima informan tersebut dipilih secara purposive sampling dan telah memberikan informasi berkaitan yang cukup banyak dengan permasalahan dalam penelitian ini.

Teknik pengumpulan data yang dilakukan yaitu metode penelitian lapangan (field work). dengan melakukan wawancara mendalam dan 
pengamatan. Adapun beberapa hal yang menjadi fokus pertanyaan terhadap kelima informan tersebut antara lain berkaitan dengan bagaimana aktifitas perempuan/ ibu rumah tangga dalam membuat pongasi dimulai dari saat mulai merencanakan membuat pongasi, proses pembuatannya, peralatan yang dibutuhkan, pantangan-pantangan yang harus dihindari saat membuat pongasi, serta berkaitan dengan jaringan distribusi pongasi tersebut, dari kalangan mana saja orang konsumennya, bagaimana cara menjualnya secara terang terangan atau sembunyi-sembunyi atau dengan menggunakan cara lain, kapan dijual dengan bagaimana wadahnya.

Demikian pula pengamatan yang telah dilakukan difokuskan pada situasi dalam konteks ruang dan waktu pada daerah penelitian. Hal ini disebabkan data yang diperoleh dari hasil wawancara saja tidaklah cukup untuk menjelaskan fenomena yang terjadi. Oleh karena itu, diperlukan suatu aktifitas dengan langsung mendatangi tempat penelitian sembari melakukan pengamatan. Pengamatan dilakukan pada setiap kegiatan atau peristiwa seperti apa yang dianggap perlu atau berhubungan dengan upaya mengungkapkan fenomena yang diangkat dalam penelitian ini. Penelitian ini bersifat kualitatif, dengan menggunakan teknik wawancara dan pengamatan untuk menjarin data. Semua data yang dihimpun dianalisa dengan menggunakan teknik analisa deskriptif kualitatif.

\section{Pembahasan}

Pembahasan mengenai perempuan pembuat pongasi di Kelurahan Wonggeduku, akan dibahas beberapa hal yang menjadi fokus penulis antara lain mengenai proses produksi pongasi dan strategi penjualan pongasi di Kelurahan Wonggeduku. Pembahasan mengenai proses penjualan pongasi pada akhirnya juga berkaitan dengan strategi penduduk setempat agar proses penjualan pongasi kepada siapa saja yang membutuhkannya (konsumen) dapat lebih aman dari pengawasan pihak kepolisian.

\section{A. Pembuatan Pongasi di Kelurahan Wonggeduku}

Proses pembuatan pongasi dibuat dengan cara yang sederhana sehingga hanya membutuhkan bahan dan peralatan yang sederhana pula. Pemilihan bahan dasar membuat pongasi merupakan hal yang penting dalam membuat pongasi. Bahan dasar yang dibutuhkan adalah beras dan ragi. Beras tersebut dapat berupa beras putih biasa ataupun beras ketan. Namun 
umumnya mereka lebih memilih beras biasa karena cenderung lebih murah bila dibandingkan dengan beras ketan. Beras tersebut harus putih bersih dan tidak berbau (kuning), karena beras yang kuning akan menghasilkan minuan pongasi yang tidak bagus, agak berbauh busuk (tidak lazim), serta berwarna kuning pula, yang akan berdampak pada kurang diminatinya pongasi yang dibuat tersebut. Umumnya pongasi yang diminati adalah yang berwarna putih bersih atau berwarna hitam. Warna hitam berasal dari beras ketan hitam, namun karena harganya yang cukup mahal, membuat mereka tidak menggunakan beras tersebut sebagai bahan utama pembuatan pongasi. Selanjutnya, dalam sekali membuat pongasi, dibutuhkan sekitar 5 liter beras atau lebih. Demikian pula keluarga perempuan pembuat pongasi yang juga memiliki lahan sawah garapan yang rata-rata luasnya antara $1 / 2$ Ha hingga $1 \mathrm{Ha}$, yang memungkinkan mereka menyimpan beras dalam jumlah yang cukup selama satu musim tanam untuk dikonsumsi seharihari maupun untuk dijadikan sebagai bahan dasar pembuatan pongasi

Masyarakat Wonggeduku umumnya tidak kesulitan untuk memperoleh beras sebagai bahan pembuatan pongasi, karena mayoritas penduduk di Kelurahan. Wonggeduku juga menanam komoditi padi di lahan persawahan baik yang mereka miliki sendiri ataupun mengolah sawah milik orang lain dengan sistem bagi hasil.

Selain itu, bahan dasar kedua yang penting pula adalah ragi. umumnya perempuan pembuat pongasi mendapatkan ragi dengan cara membeli di pasar desa karena ragi cukup banyak dijual dengan harga Rp. 500,- perbiji. Ragi tersebut berbentuk kepingan pipih yang bulat yang berdiameter sekitar $4-5 \mathrm{~cm}$. Untuk 5 liter beras, akan dibutuhkan 2 keping ragi. Ragi tersebut terlebih dahulu harus dihaluskan, karena akan ditaburkan di atas nasi yang telah matang.

Sedangkan peralatan yang dibutuhkan dalam membuat pongasi diantaranya adalah $O$ dapo (tungku tanah), Kawali (Wajan) dan tambelo (alat penggaruk), Olenga (Panci Kukusan) dan Katoa (Baskom/Tempayan), Olenga (Panci Kukusan) dan Katoa (Baskom/Tempayan), alat penyaring, $O$ Duku (Penampih/Tapisan Beras), wadah pengemasan, O Duku (Penampih/ Tapisan Beras).

Proses pembuatan pongasi dimulai dari proses menanak nasi, mendinginkan, pemeraman, penyaringan hingga pengemasan. Untuk lebih je- 
lasnya dipaparkan secara deskriptif masing-masing tahap sebagai berikut :

a. Proses menanak nasi

Proses menanaknasi denganterlebih dahulu mempersiapkan beras yang akan dimasak. Beras tersebut harus telah dibersihkan dari ampas kulit padi ataupun sisa padi (pae-pae) yang biasanya masih ada ketika padi digiling di mesin Huller (mesin penggilingan padi). Proses membersihkan ampas tersebut dilakukan dengan menggunakan tampisan beras yang biasanya terbuat dari belahanbelahan bambu yang ditipiskan lagi ataupun berupa plastik. Selanjutnya beras dicuci sebanyak 2 kali dengan air yang bersih. Tujuannya cukup seerhana yakni untuk membersihkan beras dari ampas padi (pae-pae) yang masih tersisa, dengan menggunakan alat penampih beras ataupun untuk membersihkan beras dari debu yang menempel pada beras.

Ketika proses di atas berlangsung, wajan besar (kawali owose) berisis air bersih telah terlebih dahulu dinaikkan ke atas tungku (o dapo). Hal ini dimasksudkan untuk mempersingkat waktu menanak nasi. Dalam arti bahwa mereka (kaum perempuan) melakukan beberapa pekerjaan dalam waktu yang sama. Hal ini tidak cukup merepotkan mereka karena telah terbiasa dengan hal tersebut. Selanjutnya, beras yang telah bersih dimasukkan ke dalam wajan. Takaran air harus pula diperhatikan yakni ruo tuwe (dua ruas jari) dari permukaan beras. Beras lalu terus menerus diaduk menggunakan tambelo (alat pengaduk dari kayu). Api di tungku harus terus diperhatikan agar jangan terlalu besar, karena hal tersebut akan membuat beras yang dimasak awal akan menjadi hangus. Selain itu juga harus terus menerus diaduk, dibolak balik hingga airnya mengering.

Selanjutnya, wajan diturunkan dari tungku, dan digantikna dengan panci kukusan sebagaimana yang telah penulis paparkan sebelumnya. Panci kukusan tersebut diisi air secukupnya. Umumnya beras dimasukkan ke dalam panci kukusan jika air dalam panci telah mendidih. Namum ada pula kaum perempuan yang langsung memasukkan beras yang setengah matang ke dalam panci kukusan meskipun air di dalam panci belum mendidih. 
Selanjutnya, nasi yang setengah matang tadi terus dikukus hingga benar-benar masak. Cara mengetahuinya cukup diambil beberapa butir nasi lalu ditekan di bidang yang agak rata. Jika nasi tersebut ketika ditekan tidak menyisakan bagian beras yang masih keras, hal itu menandakan bahwa nasi telah matang. Biasanya pada bagian tengah berwarna agak lebih putih dibandingkan bagian dari butir nasi yang telah matang pada bagian tepinya. Agar matangnya nasi lebih singkat dan merata, maka harus terus diaduk paling tidak sebanyak tiga atau empat kali.

b. Pendinginan (Mombokomorini) dan pemberian ragi

Proses berikutnya adalah pendinginan, nasi yang telah matang selanjutnya dipindahkan ke dalam baskom yang besar untuk didinginkan. Proses pendinginan akan memakan waktu sekitar 3-4 jam atau lebih tergantung dari banyaknya beras yang dimasak. Untuk mempercepat dingin informan ibu Maemunah biasanya mengaduk-aduk pakai tambelo, dan bahkan kalau perlu harus dikipas-kipas. Nasi yang telah dimasak memang harus segera didinginkan dengan cara demikian, karena pemberian ragi tidak bisa dilakukan dalam keadaan nasi masih mengeluarkan uap panas. Ragi tidak akan mampu bekerja menhasilkan pongasi yang baik dalam kondisi tersebut. Upaya mempercepat pendinginan juga dapat dilakukan dengan cara yang sederhana lainnya seperti menggunakan alat pengipas sambil mengaduk-aduk nasi tersebut dengan menggunakan tambelo.

Pendinginan nasi bahan pongasi juga dapat saja dibiarkan sebagaimana dilakukan oleh beberapa kaum perempuan pembuat pongasi yang lain. Mereka tidak melakukan tindakan seperti cara di atas, tetapi cukup membiarkan nasi tersebut menjadi dingin sendiri. Hal ini dilakukan terutama jika mereka juga melakukan pekerjaan lain pada waktu yang bersamaan. Hal ini menunjukkan bahwa proses pendinginan nasi yang dilakukan tampaknya masih sangat sederhana.

Setelah proses pendinginan (mombokomarini), maka proses selanjutnya adalah pemberian ragi. ragi terlebih dahulu dipecah hingga halus atau menjadi seperti bubuk, lalu ditaburkan 
secara merata pada nasi yang telah dingin. Ragi merupakan bahan yang sangat penting dalam proses ini, karena tanpa ragi maka proses fermentasi yang menghasilkan pongasi tidak akan terjadi. Agar proses fermentasi berlangsung sempurna, maka ragi terlebih dahulu harus haluskan hingga menyerupai bubuk. Dengan demikian akan memudahkan proses pemberian ragi. Ragi yang telah halus selanjutnya di taburkan di atas nasi yang telah dingin sambil terus diaduk dengan menggunakan tambelo.

c. Penyimpanan (Pemeraman)

Proses selanjutnya adalah proses penyimpanan, proses ini berlangsung selama empat hingga lima hari. Menurut Ibu Santi bahwa apa bila sudah dikasi ragi, selanjutnya disimpan selama kurang lebih empat hingga lima hari. Pada dua malam pertama setelah diperam. Nasi yang telah diberi ragi selanjutnya akan mengeluarkan cairan yang disebut sebagai wulele pongasi. Wulele pongasi merupakan air pongasi yang berwarna lebih keruh (putih) dibandingkan air pongasi yang kedua. Wulele pongasi dihasilkan sebagai hasil fermentasi antara ragi dengan nasi yang menghasilkan air pongasi.

Menurut informan Maemunah bahwa terdapat beberapa perlakuan terhadap wulele pongasi ini. Ada yang memisahkan wulele pongasi dengan air pongasi yang dihasilkan kedua kali. Ada pula yang langsung menambahkan air ke pongasi yang telah disimpan terlebih dahulu selama 2 hari. Untuk perlakuan yang pertama, setelah nasi diperam atau disimpan selama 2 hari dengan ditutupi kain yang bersih, maka fermentasi ragi dengan nasi akan menghasilkan air pongasi yang berwarna lebih keruh dibandingkan air pongasi yang dihasilkan kedua kalinya yang dikenal sebagai wulele pongasi. Wulele pongasi selanjutnya diambil dan disimpan dalam wadah tersendiri. Wulele pongasi sebagai hasil dari fermentasi tersebut biasanya akan mengendap di bagian atas dari nasi bahan pongasi tersebut. Pemisahan wulele pongasi dengan air hasil fermentasi yang kedua sebenarnya berkaitan dengan persoalan harga dari dua jenis pongasi tersebut bahwa wulele pongasi cenderung lebih tinggi harganya yakni sekitar Rp. 20.000,- , 
sedangkan air pongasi yang kedua kali biasanya dijual dengan harga Rp. 8.000,. Hal ini akan dibahas lebih lanjut dalam distribusi pongasi pada bagian yang lain.

d. Pengemasan

Proses terakhir dari proses pembuatan pongasi adalah pengemasan. Sebagaimana pada proses-proses sebelumnya, maka proses pengemasan juga dilakukan secara sederhana dengan memanfaatkan limbah yakni botol kemasan minuman yang biasanya terbuat dari bahan kaca. Berdasarkan hasil pengamatan peneliti bahwa proses ini berlansung setelah nasi disimpan selama 4 atau 5 malam sejak pertama kali diberi ragi. Ada tiga cara yang ditempuh oleh perempuan pembuat pongasi dalam pengemasan pongasi itu sendiri yakni 1) menyimpan pongasi di dalam botol bekas kemasan minuman; 2) menyimpan air pongasi di dalam baskom; 3) Menimpannya dalam jerigen. Hal ini sebenarnya juga berkaitan dengan kepraktisan daam proses penjualan pongasi.

\section{B. Strategi Penjualan Pongasi}

Aktifitas yang penting lainnya yang juga dilakukan oleh kaum perempuan pembuat pongasi adalah aktivitas penjual pongasi itu sendiri karena melalui aktivitas inilah membuat aktivitas membuat pongasi menjadi berarti dan memberikan kontribusi ekonomi bagi kehidupan keluarga pembuat pongasi. Karena melalui aktifitas menjual pongasi tersebutlah mereka akan memperoleh sejumlah uang yang berguna untuk memenuhi berbagai bentuk keperluan keluarga mereka.

Ada strategi yang umum digunakan oleh perempuan pembuat pongasi dalam memasarkan pongasi yang telah dibuat (diproduksi) diantaranya sebagai berikut :

a. Menjual di rumah.

Menjual di rumah merupakan cara yang umum dilakukan oleh kaum perempuan pembuat pongasih di daerah ini, seperti dijelaskan informan ibu Murni bahwa selama ini saya jual pongasi di rumah saja, karena lebih aman, paling sekitar 3 hari sudah habis lagi. Harganya tidak terlalu berbeda dengan di pasar yakni 1 botol saya jual Rp. 8.000 kalau tidak ada wulele pongasinya, tapi kalau saya campur dengan wulelenya saya jual Rp 10.000. Kalau 
memakai takaran botol minuman topi miring. harganya Rp 10 000, tapi kalau botol abc harganya Rp. Rp. 8.500,-

Berdasarkan data wawancara dan pengamatan menunjukkan bahwa salah satu cara yang dilakukan perempuan pembuat pongasi di Kelurahan Wonggeduku dalam memasarkan pongasinya adalah dengan metode penjualan pasif, dimana pongasi dijual di rumah, itupun secara sembunyi-sembunyi. Hal tersebut disebabkan pihak kepolisian kerap kali melakukan razia terhadap kepemilikan pongasi warga meskipun tidak kontinyu. Fokus razia biasanya tertuju pada kalangan pembuat pongasi di daerah ini. Oleh karena itu, mereka (pembuat pongasi) harus memiliki strategi untuk menjual pongasi tersebut. Salah satunya adalah dengan menjualnya di rumah dengan pasif.

Menjual pongasi di rumah selain pilihan keamanan (terhindar dari razia pihak kepolisian), mereka juga merasa tidak perlu menjualnya hingga ke pasar atau menjualnya di kios. Karena penduduk sekitar yang ingin menikmati pongasi telah mengetahui dimana seharusnya mereka dapat memperoleh pongasi tersebut. Informasinya biasanya diperoleh dari mulut ke mulut. Warga yang ingin menikmati pongasi cukup datang langsung ke rumah penjual pongasi.

Dari hasil pengamatan penulis. ada hal yang unik dalam proses penjualan pongasi ini, di mana warga yang ingin membeli pongasi biasanya dilakukan pada malam hari bahkan tengah malam baru asik berpesta pongasi. Hal ini tentu saja cukup aman bagi pembeli maupun orang yang menjual pongasi dari penggerebekan oleh polisi. Namun demikian pembeli pongasi pada siang hari tetap saja ada namun mereka umumnya datang seorang diri tidak beramai-ramai seperti malam hari. Serta tentu saja telah membawa jerigen sebagai wadah pongasi. Penggunaan jerigen tampaknya lebih praktis untuk dibawa dibandingkan jika menggunakan botolbotol yang sebelumnya telah disediakan oleh penjual pongasi. Penduduk setempat jika membeli pongasi tidak hanya dalam jumlah sedikit misalnya 1 botol, tetapi dalam jumlah yang lebih besar yakni 3 botol hingga lima botol. Jumlah tersebut tentu saja 
akan lebih praktis jika ditempatkan dalam wadah yang lebih besar. Pilihan warga biasanya adalah jerigen yang umumnya juga dimiliki oleh hampir semua warga khususnya jerigen dengan ukuran berat bersih 5 liter. Warga setempat khususnya yang kaum pria baik remaja dan dewasa umumnya menenggak pongasi secara bersamasama yakni sekitar 4 hingga 5 orang dan bahkan bisa lebih banyak lagi. Sehingga tentu sjaa mereka membutuhkan pongasi yang lebih banyak.

Hasil wawancara dengan ibu Murni secara eksplisit menunjukkan mengenai harga jual sebotol pongasi yakni berkisar Rp. 8.000,- untuk untuk air pongasi yang tidak dicampur dengan wulele pongasi. Biasanya merupakan hasil fermentasi yang kedua. Setelah pongasi ditambahkan air secukupnya. Sedangkan jika dicampurkan wulele pongasi, maka harga cenderung akan lebih tinggi yakni Rp. 10.000,-. Tentu saja kadarnya semakin tinggi pula jika dibandingkan dengan yang tidak dicampur wulele pongasi.

b. Menjual di pasar.

Cara yang kedua ditempuh oleh perempuan pembuat pongasi dalam menjajakan pongasinya adalah dengan menjualnya di pasar. Pasar merupakan tempat transaksi yang memerlukan strategi karena di tempat tersebut banyak orang melakukan transaksi, sehingga penjual susah membedakan mana pembeli dan mana petugas yang biasa menyita pongasi, oleh karena itu penjual pongasi cenderung mengaburkan aktifitas jual beli pongasi. Hal seperti ini dijelaskan oleh Ibu Murni bahwa menjual di pasar supaya aman bukan hanya pongasi saja dijual, tetapi juga ada sayur, kelapa, karena di belakang rumah ada pombahora ditanami sayur-sayuran.

Menjual pongsi di pasar juga ternyata menjadi pilihan bagi kaum perempuan pembuat pongasi, selain menjualnya di rumah. Tentu saja dari aspek keamanan tentu saja menjual di rumah lebih aman. Aman yang dimaksud di sini adalah tidak kepergok oleh pihak kepolisian sedang menjual pongasi. Meskipun harus menjual di pasar, tetapi mereka memiliki strategi agar mereka dapat menjual pongasi dengan aman. Dalam hal ini, mereka menjual pongasi 
bersamaan dengan aktivitas menjual sayur-sayuran yang mereka peroleh dari kebun mereka sendiri. Proses penjualan pongasi pun dilakukan secara tersembunyi. Pongasi akan dikeluarkan jika telah ada orang yang menanyaakan dan sudah dipastikan bukan polisi. Pongasi tidak dipajang atau diletakkan bersamaan dengan sayursayuran yang akan dijual. Harga jual pongasi yang dijual di pasar tidak berbeda jauh dengan harga pongasi yang dijual di rumah. Hal ini dilakukan untuk memberikan pilihan yang fleksibel bagi orang yang ingin membeli pongasi. Memilih membeli pongasi di rumah pembuat pongasi atau justru lebih memilih membeli pongasi di pasar pada penjual yang sama.

c. Menjual ke Warga Desa Tetangga

Cara yang ketiga juga ditempuh untuk menjual pongasi adalah dengan membawa kepada warga desa tetangga. Meskipun sebenarnya pada akhirnya pembelilah yang harus mendatangi rumah penjual pongasi tersebut. Hal ini biasanya dilakukan dengan terlebih dahulu kaum suami dari perempuan yang membuat pongasi melakukan promosi kepada warga desa tetangga. Hal ini dijelaskan oleh Ibu Ndebo bahwa kadang-kadang juga kita jual di desa sebelah. Suami saya sering pergi di acara-acara kematian atau membantu mondumba (membuat atau mendirika tenda untuk pesta di desa sebelah). Biasanya setelah selesai mendirikan tenda, para pekerja tersebut selalu mereka minum pongasi. Demikian juga ketika pesta pada malam hari, banyak anak-anak remaja yang memesan pongasi, untuk diminum secara beramai-ramai di rumah sekitar tempat pesta.

Hasil wawancara menunjukkan bahwa salah satu cara yang ditempuh oleh kaum perempuan pembuat pongasi untuk menjajakan pongasi yang mereka buat adalah menjajakan di desa tetangga terutama ketika ada pesta. Hal tersebut dilakukan dengan selalu berkunjung ke desa-desa tetangga untuk membantu ketika warga di desa tetangga mengadakan hajatan baik hajatan perkawinan ataupun hajatan lainnya, yakni di mana sang suami atau bahkan kaum perempuan pembuat pongasi itu sendiri melakukan promosi. Tentu saja promosi yang dilakukan berlangsung dari 
mulut ke mulut serta dengan jeli melihat kondisi orang-orang yang bekerja membantu di hajatan tersebut. Jika para pekerja tersebut membutuhkan pongasi untuk minum secara bersama-sama, maka saat itulah mereka menawarkan pongasi tersebut. Bahkan mereka terkadang tidak perlu lagi menawarkan pongasi, karena para pekerja tersebut akan langsung datang membeli pongasi ke rumah penjual pongasi biasanya atas rekomendasi dari orangorang dihajatan tersebut juga. Terkadang pula pemilik pongasi sendiri yang mengambil pongasi tersebut ke rumahnya setelah ada kesepakatan mengenai harga dan jumlah pongasi yang akan dibeli.

Namun demikian, proses penjualan pongasi dengan cara seperti ini juga jarang dilakukan. Karena hal yang paling umum terjadi adalah bahwa pembeli pongasi biasanya tidak langsung membayar harga pongasi pada saat itu juga. Dengan kata lain, pembeli akan berutang kepada pembuat pongasi. Hal seperti ini, rentan terhadap kemungkinan bahwa pongasi tidak akan dibayar oleh pembeli. Sehingga, kaum perempuan pembuat pongasi juga menekankan bahwa jika ingin membeli, maka harus langsung melakukan pembayaran pada saat pongasi diserahkan. Mengapa demikian ?, karena uang hasil penjualan pongasi tersebut selanjutnya akan digunakan lagi oleh mereka untuk membuat pongasi lagi. Untuk meminimalisir pembeli yang berutang, biasanya pemilik pongasi akan menawarkan pongasi kepada sekelompok orang yang ingin minum pongasi setelah ada kepastian siapa yang akan membayar,entah dengan cara patungan atau dengan cara lain. Bahkan setelah uang diterima oleh pemilik pongasi.

\section{Pandangan Masyarakat Terhadap Tradisi Minum Pongasi}

Pandangan masyarakat Desa Wenggeduku Kabupaten Konawe meyakini bahwa tradisi minum pongasi yang dilakukan saat pesta pernikahan atau pada momen-momen khusus bukan kebiasaan yang jelek karena sudah menjadi tradisi dan budaya di desa tersebut dan mereka beranggapan wajib dilestarikan. Selain itu kegiatan ini juga merupakan wujud penghargaan tuan rumah terhadap tamu undangan yang datang. Tuan rumah menyediakan pongasi tapi bukan berarti tuan rumah mengajak para tamu 
undangan untuk mabuk-mabukan, tetapi lebih untuk menghormati dan menghargai tamu. Selain itu tradisi minum pongasi hanya sebatas untuk menghangatkan, meramaikan dan menciptakan suasana akrab dalam suatu pesta atau perayaan. Minum pongasi hanya sebatas membuat suasana pesta lebih hangat, suasana lebih ramai dan lebih akrab.

Selain itu masyarakat Desa Wenggeduku mempunyai kepercayaan yaitu sikap untuk menerima suatu pernyataan atau pendirian, tanpa menunjukkan sikap pro atau anti. Artinya, jika orang percaya bahwa merokok dan minum-minuman keras tidak baik untuk kesehatan, maka dianggapnya hal itu adalah benar, terlepas dari apakah dia suka atau tidak suka merokok atau minum-minuman keras. Seringkali suatu kepercayaan tumbuh dan berkembang dalam masyarakat dimana anggota-angotanya mempunyai kepentingan dan tujuan yang sama. Tidak jarang pula kepercayaan kelompok ini (group belief) ditumbuhkan oleh pihak yang berwenang atau pemimpin masyarakat yang disebarluaskan ke anggota masyarakat lainnya.

Seperti yang terjadi di Desa Wenggeduku dengan penyalahgunaan produksi pongasi, para tokoh agama dan tokoh masyarakat telah berulangkali memberikan nasehat bahwa minum-minuman keras itu dilarang agama dan berdampak buruk pada kesehatan. Namun yang terjadi, walaupun sudah ada kepercayaan dan pandangan yang sama mengenai dampak buruk minum-minuman keras, tetaplah masih ada yang melakukannya juga. Kepercayaan tentang apa yang dianggap baik/benar dan apa yang dianggap tidak baik/salah disebut nilai. Nilai sosial mencerminkan budaya suatu masyarakat dan berlaku bagi sebagian besar anggota masyarakat penganut kebudayaan tersebut. Jika individu menerima sutu nilai tertentu, dia dapat menjadikannya sebagai tujuan hidupnya.

Dari hasil wawancara dan pengamatan langsung peneliti, maka untuk mengatur perilaku individu dalam kelompok agar sesuai dengan nilainilai yang berlaku dibuatlah norma-norma tertentu, berupa peraturan yang disetujui oleh anggota masyarakat, yang menguraikan secara rinci tentang perilaku yang harus atau justru tidak boleh dilakukan dalam suatu keadaan atau kedudukan tertentu. Norma sosial kadang-kadang juga mencakup jenis sangsi atau imbalan yang akan diberikan kepada mereka yang melanggar atau mematuhi peraturan tersebut. Jadi norma sosial ini digunakan sebagai mekanisme kontrol perilaku individu dalam masyarakat. 
Norma sosial di desa Wenggeduku mengenai tradisi perempuan yang berkerja di sektor informal sebagai pembuat pongasi dan kebiasaan minum-minuman keras perlu didekati secara perlahan-lahan dari berbagai sudut pandang masyarakat, khususnya dari sudut ajaran agama maupun dampak buruknya. Walaupun pendekatan tersebut terkadang berbenturan dengan norma budaya masyarakat tersebut yang telah diturunkan dari jaman nenek moyangnya. Selain itu perlu adanya sanksi yang tegas bagi individu yang melakukannya juga masih longgar.

Hukum Islam pun melarang minuman keras termasuk bir bukan hanya kepada pelaku peminumnya saja, tetapi juga pengedaran, pemilikan dan itu berarti sekaligus produsennya. Jadi meminum minuman beralkohol, sedikit atau banyak, hukumnya haram. Demikian pula dengan kegiatan memproduksi, mengedarkan, memperdagangkan, membeli, menikmati hasil/keuntungan dari perdagangan minuman beralkohol.

\section{Pandangan Masyarakat Terhadap Perempuan Pembuat Pongasi}

Pandangan masyarakat Desa Wenggeduku Kabupaten Konawe terhadap perempuan pembuat pongasi secara umum masih dipandang hal yang biasa dan wajar. Bagi mereka kegiatan tersebut merupakan kegiatan yang sudah turun temurun dan menjadi bagian budaya masyarakat yang harus dipertahankan. Akan tetapi perlindungan hukum bagi perempuan yang bekerja di sektor ini masih sangat lemah dan belum adanya sosialisasi dari pihak-pihak terkait akan larangan pembuatan pongasi.

Selain itu dukungan tokoh adat dan tokoh masyarakat yang meyakini bahwa tradisi minum pongasi yang dilakukan saat pesta pernikahan atau pada momen-momen khusus bukan kebiasaan yang jelek menjadi salah satu penguat tradisi pembuatan pongasi yang tetap bertahan sampai saat ini.

\section{Penutup}

Perempuan pembuat pongasi di Kelurahan Wenggeduku pada umumnya adalah ibu rumah tangga yang secara sosial dipandang rendah dan kurang mendapat perlindungan hukum. Padahal dalam kenyataannya mereka sebagai penopang ekonomi keluarga karena pendapatan suami yang tidak mencukupi kebutuhan hidup sehari-hari.

Pendapatan perempuan pembuat pongasi dalam setiap kali mem- 
buat pongasi cukup tinggi untuk ukuran di kecamatan karena bisa mencapai keuntungan sekitar Rp 150.000,- setelah dikurangi biaya produksi dan biaya penjualan. Oleh karena itulah banyak perempuan di kelurahan ini membuat pongasi walaupun pekerjaan tersebut dilarang polisi karena dianggap sebagai pemicu terjadinya perkelahian antar remaja.

Pongasi sebagai minuman yang mengandung alkohol sehingga peredarannya dibatasi dan bahkan dilarang untuk dikonsumsi, namun kenyataannya permintaan minuman ini cukup tinggi terutama ketika ada pesta-pesta perkawinan atau perayaan hari-hari besar nasional. Untuk dapat memasarkan hasil produksinya perempuan pembuat pongasi melakukan beberapa strategi penjualan diantaranya cara menjual pasif di rumah, atau menjual sayuran akan tetapi yang pokok adalah pongasi untuk mengelabui polisi.

\section{DAFTAR PUSTAKA}

(1985). Manusia dan Kebudayaan di Indonesia. Yogyakarta: Djambatan

Abdullah, Irwan. (2000). Sangkan Paran Gender. Yogyakarta: Pusat Penelitian Kependidikan (PPK) Universitas Gadjah Mada.

Endraswara, Suwardi. (2000). Metodologi Penelitian Kebudayaan. Yogyakarta: Gadjah Mada University Press.

Hemas, GKR. (1992). Perempuan Indonesia Suatu Konsepsi dan Obsesi, Yogyakarta; Liberty.

Husna, Lilis Nurus. (2001). Posisi Korpri Dalam Arus Gerakan Reformasi, Majalah Ilmiah Perempuan Bergerak, Pemikiran Refleksi

Demokrasi. Jakarta: Pengurus Besar Korp. PMII Putri.

Koentjaraningrat. (1981). Pengantar Antropologi. Jakarta: Rineka Cipta.

Laksono, PM, dkk. (2000). Perempuan di Hutan Manggrove, Kearifan Ekologis Masyarakat Papua. Yogyakarta: Galang Press dan Yayasan Kehati.

Maleong, (1999). Metodologi Penelitian Kualitatif, Bandung: PT. Rosda Karya.

Mosse, Julia Cleves. (1993). Gender dan Pembangunan. Yogyakarta: 
Kerja sama Rifka Annisa Women's Crisis Centre dengan Pustaka Pelajar.

Purba, Joni. (2005). Ketimpangan Gender dan Bertahannya Konstruksi Patriarkhi Dalam Masyarakat Karo”. Dalam Jurnal Antropologi Sosial Budaya ETNOVISI Vol. I No. 1 Medan: LPM Antropologi, USU.

Sairin, Syafri, dkk. (2002). Pengantar Antropologi Ekonomi. Yogyakarta: Pustaka Pelajar.

SarwonoS., 1997,SosiologiKesehatanbeberapaKonsepBesertaAplikasinya, Yogyakarta : UGM Press.

Sofia Kartika.2005. Perempuan Pesisir dan Pemberdayaan Ekonomi Kendari. Jurnal Perempuan No. 42 .Jakarta:Yayasan Jurnal Perempuan.

Spradley, P. James. 1997. Metode Etnografi. Yogyakarta: Tiara Wacana. Sumijati. 2001. Dinamika dan Pembangunan Masyarakat Indonesia. Yogyakarta: Tiara Wacana. 